\title{
PATHOGEN-RELATED SPECIFICITY OF SUBTILASE VVISBT4.19 X1 IN THE VITIS VINIFERA DEFENCE RESPONSE
}

\section{ESPECIFICIDADE PATOGÉNICA DA SUBTILASE VVISBT4.19 X1 NA RESPOSTA DE DEFESA DA VITIS VINIFERA}

\author{
Joana Figueiredo $^{1,2}$, Jorge Cunha ${ }^{3,4}$, José Eiras-Dias ${ }^{3,4}$, Marta Sousa Silva ${ }^{2^{*}}$, Andreia Figueiredo ${ }^{1^{*}}$ \\ ${ }^{1}$ BioISI - Biosystems \& Integrative Sciences Institute, Faculdade de Ciências da Universidade de Lisboa, 1749-016 Lisboa, Portugal. \\ ${ }^{2}$ Laboratório de FTICR e Espectrometria de Massa Estrutural, Faculdade de Ciências da Universidade de Lisboa, 1749-016 Lisboa, Portugal. \\ ${ }^{3}$ Instituto Nacional de Investigação Agrária e Veterinária, Quinta de Almoinha, 2565-191 Dois Portos, Portugal. \\ ${ }^{4}$ Green-it Unit, Instituto de Tecnologia Química e Biológica, Universidade Nova de Lisboa, 2780-157 Oeiras, Portugal. \\ * Corresponding author: Tel.: +351 217500000; e-mail: aafigueiredo@fc.ul.pt, mfsilva@fc.ul.pt
}

(Received 14.05.2020. Accepted 01.07.2020)

\section{SUMMARY}

Grapevine, Vitis vinifera L., is one of the most cultivated fruit plants worldwide with high economic value. Powdery mildew and gray mold diseases, caused by Erysiphe necator and Botrytis cinerea, respectively, are within the most devastating diseases, which are controlled by using several fungicide applications over a single growing season. A more sustainable and environmentally friendly alternative for pest control is associated to the development of breeding programs, in which American and Asian Vitis species, presenting natural resistance characteristics, are crossed with $V$. vinifera varieties that are susceptible to diseases caused by fungal or oomycete pathogens. As a result, new grapevine varieties that combine the good berry quality with a high degree of resistance to grapevine pathogens are obtained. One example is the Vitis vinifera cv 'Regent' that acquired high tolerance degree against E. necator and Plasmopara viticola. To ensure durable resistance introgression in breeding programs, a full understanding of grapevine defence mechanisms is crucial. Previous studies on grapevine- $P$. viticola pathosystem have suggested the participation of serine proteases in the establishment of the interaction between both organisms, which is the case of VviSBT4.19 X1. The gene expression of this subtilase increases up to 300-fold 6 hours after 'Regent' inoculation with $P$. viticola. Nowadays, no information is available about the participation of subtilases in grapevine response to E. necator and B. cinerea infection. In the present study, the gene expression profile of VviSBT4.19 X1 in the first hours of 'Regent' inoculation with E. necator and B. cinerea was analysed to understand its response towards different pathogenic agents.

\section{RESUMO}

A videira, Vitis vinifera L., é uma das plantas de fruto mais cultivadas em todo o mundo, possuindo um elevado valor económico. As doenças do oídio e da podridão cinzenta, causadas pelo Erysiphe necator e pela Botrytis cinerea, respetivamente, estão entre as doenças mais devastadoras da videira, cujo controlo é feito através de diversas aplicações de fungicidas ao longo de cada ciclo vegetativo. Uma alternativa mais sustentável para o controlo de pragas está relacionada com os programas de melhoramento, em que espécies de Vitis americanas e asiáticas, que possuem características intrínsecas de resistência, são cruzadas com videiras suscetíveis a doenças causadas por fungos ou oomicetes. Como resultado, são desenvolvidas novas variedades que combinam as características que definem a boa qualidade da uva com as que conferem um elevado grau de resistência aos patógenos. Um exemplo é a $V$. vinifera cv 'Regent' que adquiriu um elevado grau de tolerância contra o E. necator e o Plasmopara viticola. Para garantir uma introgressão duradoura da resistência nestes programas, é essencial compreender os mecanismos de defesa da videira. Estudos anteriores realizados na interação videira- $P$. viticola sugeriram a participação das subtilases no estabelecimento desta interação, como é o caso da VviSBT4.19 X1. Verificou-se que esta subtilase é constitutivamente mais expressa em genótipos de videira tolerantes e que a sua expressão genética aumenta até 300 vezes 6 horas após a infeção do $P$. viticola na cultivar 'Regent'. Até ao momento, não há informações disponíveis sobre a participação das subtilases na resposta de defesa da videira à infeção pelo E. necator e $B$. cinerea. Neste estudo foi analisado o perfil de expressão genética da VviSBT4.19 X1 nas primeiras horas após inoculação da cultivar 'Regent' com E. necator e B. cinerea de forma a compreender a resposta deste gene a diferentes agentes patogénicos.

Key words: Subtilisin-like proteases, grapevine, downy and powdery mildews, gray mold.

Palavras-chave: Proteases do tipo subtilisina, videira, míldio, oídio, podridão cinzenta.

This is an Open Access article distributed under the terms of the Creative Commons Attribution License (http://creativecommons.org/licenses/by/4.0), which permits unrestricted use, distribution, and reproduction in any medium, provided the original work is properly cited. 


\section{INTRODUCTION}

Vitis vinifera L. is a domesticated Vitis species as a result of natural and human influences for thousands of years leading to the development of about 5000 different grapevine varieties worldwide (This et al., 2006). In Portugal, there are about 250 different grapevine varieties, placing Portugal in the third position in the world for the number of grapevine varieties (Martins, 2018). In 2018, grapevine was one of the most cultivated crops with over $7.4 \mathrm{kHa}$ of plantation and 292 million of hectolitres $(\mathrm{mhL})$ of wine produced (excluding juice and must) (OIV, 2019).

The domesticated grapevines widely used for fruit and wine production do not present a natural resistance to several fungal and oomycete driven diseases. Within grapevine diseases, powdery mildew, caused by the biotrophic obligate oomycete Erysiphe necator (Schwein.) is one of the most destructive ones. This oomycete depends on genus Vitis to growth and development, and for infection it needs warm temperatures $\left(23{ }^{\circ} \mathrm{C}\right.$ to $\left.30{ }^{\circ} \mathrm{C}\right)$ and relative humidity of approximately $85 \%$ (Gadoury et al., 2012). To penetrate the leaf, E. necator needs to cause a wound on the adaxial face of the leaf, so the conidium attaches to the tissue cells allowing the formation of a primary germ tube that differentiates into a specialized infectious structure, the appressorium. This causes a mechanical pressure on the leaf surface which results in the penetration of the pathogen in the host cells. After invasion, E. necator develops an haustoria that penetrates the cell wall of the host for pathogen feeding. After haustoria establishment, a secondary hypha spreads within the leaf tissue and asexual reproductive bodies (conidiophores and conidia) emerge from them. Disease symptoms appear as a white-greyish powder on the surface of the infected tissue mostly leaves and stems. The E. necator infection causes a declining in the sugar content and acidity of the berries leading to a reduction of fruit quality (Armijo et al., 2016).

Infection caused by necrotrophic fungi also leads to several yield losses. These pathogens take advantage of existing wounds to develop their infection structures. One of the most important grapevine diseases caused by a necrotrophic fungus is the "gray mold", whose causal agent is the Botrytis cinerea Pers. Fr. This fungus is not specific to the genus Vitis and it is able to live as a parasite in green tissues and as a saprophyte in dead tissues. Fluctuations in temperature and humidity, like a rapid decrease in humidity with a rise in temperature in the early morning, cause a drying of the conidiophores with a consequent release of conidia into air currents (Jarvis,
1962). In the host, when the conidia recognize the surface nutrients, this fungus develops an appressorium that disrupt the cuticle through a penetration peg. To help in plant cell penetration, appressorium also secretes several lytic enzymes to cross cuticle and outer epithelial wall. This primary lesion leads to an oxidative burst that helps the fungus to kill and degrade the host tissue. The most typical symptoms on leaves and soft fruits are the appearance of grey masses of conidia as well as the collapse and water-soaking of parenchyma tissues. "Gray mold" disease appears along all the growing season, but most commonly occurs near the harvest time, affecting complete berry clusters and thus becoming one of the most important pathogens that affects table grapes and wine production (Dean et al., 2012; Armijo et al., 2016).

The current strategy to control these diseases is the extensive use of fungicides leading to severe environmental impacts, namely through soil and groundwater contamination. A sustainable strategy to fight these diseases is the development of new grapevine varieties through breeding programs. In these programs, the natural resistant traits found in American and Asian Vitis species are introgressed into the genome of natural susceptible $V$. vinifera cultivars through plant crossing. The new varieties will combine good berry quality with a high degree of tolerance to grapevine pathogens (Gessler et al., 2011). One successful example is the $V$. vinifera $\mathrm{cv}$ 'Regent', a plant breeding resulting from the cross between $V$. vinifera ssp vinifera cv. 'Diana' and the interspecific hybrid 'Chambourcin' (created by Professor Gerhardt Alleweldt, in 1967, at the Geilweilerhof Institute for Grape Breeding, Germany). 'Regent' presents high tolerance degree to the main pathogens that affect European viticulture, such as Plasmopara viticola (Resistance Locus RPV3.1) and E. necator (Resistance Loci Ren3 and Ren9) (Maul and Töpfer, 2015).

To ensure durable resistance introgression in breeding programs, a full understanding of grapevine defence mechanisms is crucial, particularly the response towards different pathogens. Previous studies on grapevine- $P$. viticola interaction suggested the participation of serine proteases in the establishment of the incompatible interaction (Figueiredo et al., 2016). Subtilases are serine proteases involved in several plant biological functions (Figueiredo et al., 2018). Although plant subtilases participate in several biological processes, including mobilization of storage proteins during seed germination to the initiation of cell death and senescence, they have been increasingly associated with plant defence against several pathogens, including biotrophs, hemibiotrophs, necrotrophs, insects and nematodes 
(Figueiredo et al., 2018). Interestingly, in the same plant, different subtilases can be induced as a response to different pathogens (Figueiredo et al., 2018). Specific subtilases have already been described as associated with a particular defence mechanism and pathosystem (Figueiredo et al., 2018). For example, in cotton, a subtilase called GbSBT1 was related to the induction of plant resistance against Verticillium dahliae, a necrotrophic fungus (Duan et al., 2016). In tomato, there are several evidences of the role of P69B subtilase in response to $P$. infestans and $P$. syringae (Zhao et al., 2003; Tian et al., 2004; Tian, 2005). Also, in potato, several subtilase genes have been shown to increase their expression after $P$. infestans infection (Norero et $a l ., 2016)$. In grapevine, little is known about the role of subtilases in plant response to environmental stimuli.

Previous results showed that the grapevine subtilase VviSBT4.19X1 is constitutively over-expressed in several grapevine genotypes tolerant to $P$. viticola, like 'Regent', and other Vitis species, increasing its expression up to 300 -fold 6 hours after $P$. viticola infection in 'Regent' cultivar (Figueiredo et al., 2016). At this time point, in grapevine- $P$. viticola interaction, recognition of pathogen effectors by plant membrane receptors may occur triggering an immune response. The involvement of this protease in the grapevine defence response to this oomycete was suggested. In grapevine- $E$. necator and grapevine- $B$. cinerea interactions there is no information regarding subtilase, particularly VviSBT4.19 X1, involvement in the plant response to pathogen inoculation. Hence, in this study, the expression of the VviSBT4.19 XI subtilase in the response of $V$. vinifera $\mathrm{cV}$ 'Regent' to $E$. necator and $B$. cinerea pathogens was analysed in order to understand this subtilase specificity.

\section{MATERIAL AND METHODS}

\section{Plant material}

The obtained Vitis vinifera cv. Regent, bread by multiple introgressions from resistant wild genotypes (Welter et al., 2017), was used in this study. Young fully expanded leaves, the $2^{\text {nd }}$ to $3^{\text {rd }}$ from the shoot apex, from field plants were collected in the Portuguese Grapevine Germplasm Bank (Veloso et al., 2010). Portuguese Ampelographic Collection (PRT051) is property of National Institute of Agrarian and Veterinary Research (INIAV), a governmental institute. It is located at $40 \mathrm{Km}$ of north of Lisbon, in Quinta da Almoínha, Dois Portos (9'11'19',W; 3902'31''N; $75 \mathrm{~m}$ above sea level). This collection was established in 1988, and was replicated to a new place in 2013 and 2014. All accessions are grafted on SO4 rootstock and each accession is represented by seven plants. Vine pruning system is royat double cordon, leaving only four spurs in each arm. These spurs are yearly pruned leaving only eight to nine buds in each arm and a total of 16 to 18 buds in each plant, depending upon the vigour of the plant. All agronomic treatments and canopy maintenance in the field are applied as in commercial vineyards depending on the annual weather. For this study, leaves from Vitis vinifera cv 'Regent' plants were harvested and washed in a bleach solution $(5.5 \%(\mathrm{v} / \mathrm{v})$ sodium hypochlorite) during $1 \mathrm{~min}$ and $30 \mathrm{~s}$, and then rinsed three times in distilled water. Leaves were air dried and placed in $0.8 \%(w / v)$ agar plates with the adaxial face up for Erysiphe necator inoculation and with the abaxial face up for the Botrytis cinerea inoculation. The data presented was the result of a preliminary assay. In this assay, 12 complete leaves, collected from the seven field plants, were used per treatment. Each biological replicate is represented by four leaves, from different plates.

\section{Erysiphe necator inoculation assay}

For inoculation, field grapevine leaves with symptoms of powdery mildew were collected, and Erysiphe necator spores were brushed directly to the leaves in the agar plates (average value of 8483 spores $/ \mathrm{mm}^{2}$ of leaf). Control samples without inoculation were also made. After inoculation, plates were kept in a climate chamber under a 16/8 h (light/dark) at $25{ }^{\circ} \mathrm{C}$ and with a relative humidity ranging between 40 and $95 \%$. Leaves were collected at 6 and 24 hours post inoculation (hpi), immediately frozen in liquid nitrogen and stored at $-80{ }^{\circ} \mathrm{C}$. Three independent biological replicates were obtained.

\section{Botrytis cinerea inoculation assay}

Botrytis cinerea was cultured in Petri dishes on potato dextrose agar (PDA) medium (Merck, Germany) at $20{ }^{\circ} \mathrm{C}$ for 8 days. Conidial suspension was obtained by flooding the fungal culture with sterile distilled water and rubbing the mycelium. The conidial suspension was adjusted with sterile distilled water to $2.5 \times 10^{5}$ conidia/mL. Inoculum solution concentration was confirmed using a Neubauer counting chamber. For inoculation, grapevine leaves were dipped in the conidia solution and placed on the agar plates. Negative controls using water were also made. The plates were kept in a climate chamber under a 16/8h (light/dark) with temperature and relative humidity ranging between $22{ }^{\circ} \mathrm{C}-25{ }^{\circ} \mathrm{C}$ and $60-90 \%$, respectively. Samples were collected at 6 and $24 \mathrm{hpi}$, immediately frozen in liquid nitrogen, and stored at 
$-80{ }^{\circ} \mathrm{C}$. Three independent biological replicates were obtained.

\section{RNA extraction and cDNA synthesis}

Total RNA was isolated from frozen leaves using the Spectrum ${ }^{\mathrm{TM}}$ Plant Total RNA Kit (Sigma-Aldrich, USA) according to the manufacturer's instructions. Residual genomic DNA (gDNA) was digested with DNase I (On-Column Dnase I Digestion Set, SigmaAldrich, USA). RNA integrity was verified by agarose gel electrophoresis $(1.2 \%(\mathrm{w} / \mathrm{v})$ agarose in TAE buffer). RNA purity and concentration were measured at 260/280 $\mathrm{nm}$ in a spectrophotometer (Nanodrop-1000, Thermo Fisher Scientific, USA). The presence of gDNA in RNA samples was assessed by qPCR analysis (Vandesompele et al., 2002). Complementary, DNA (cDNA) was synthesized from
$2 \mu \mathrm{g}$ of total RNA using RevertAid® $\mathrm{H}$ Minus Reverse Transcriptase (Thermo Fisher Scientific, USA), anchored with Oligo(dT) $)_{23}$ primer (Thermo Fisher Scientific, USA), according to the manufacturer's instructions.

\section{Quantitative real-time PCR (qPCR)}

Quantitative real time PCR (qPCR) experiments were carried out using Maxima ${ }^{\mathrm{TM}}$ SYBR Green qPCR Master Mix (2x) kit (Thermo Fisher Scientific, USA) in a StepOneTM Real-Time PCR system (Applied Biosystems, USA). A final concentration of $2.5 \mathrm{mM}$ $\mathrm{MgCl}_{2}$ and $0.2 \mu \mathrm{M}$ of each primer were used in $20 \mu \mathrm{L}$ volume reactions, together with $4 \mu \mathrm{L}$ of cDNA (diluted 1:40) as template. Primer sequences and reaction details are provided in Table I.

Table I

Target and reference gene oligonucleotide sequences employed in the current study

Sequências oligonucleotídicas dos genes de interesse e de referência usadas no presente estudo

\begin{tabular}{|c|c|c|c|c|c|}
\hline $\begin{array}{c}\text { Identifier/ } \\
\text { NCBI Accession } \\
\text { Number }\end{array}$ & Primer sequence & $\begin{array}{l}\text { Amplicon } \\
\text { length (bp) }\end{array}$ & $\begin{array}{l}\text { Amplification } \\
\text { efficiency }(E)\end{array}$ & $\begin{array}{c}\text { Ta } \\
\left({ }^{\circ} \mathbf{C}\right)\end{array}$ & $\begin{array}{r}\mathbf{T m} \\
\left({ }^{\circ} \mathbf{C}\right)\end{array}$ \\
\hline \multicolumn{6}{|l|}{ Reference gene } \\
\hline EF1a & F:GAACTGGGTGCTTGATAGGC & \multirow{3}{*}{164} & \multirow{3}{*}{1.99} & \multirow{3}{*}{60} & \multirow{3}{*}{79.5} \\
\hline & & & & & \\
\hline$X M \_002284888.3$ & R:ACCAAAATATCCGGAGTAAAAGA & & & & \\
\hline \multirow[t]{2}{*}{ GADPH } & F:TCAAGGTCAAGGACTCTAACACC & \multirow{3}{*}{226} & \multirow{3}{*}{1.98} & \multirow{3}{*}{60} & \multirow{3}{*}{80.5} \\
\hline & & & & & \\
\hline$X M \_002263109.3$ & R:CCAACAACGAACATAGGAGCA & & & & \\
\hline \multirow[t]{2}{*}{$S A N D$} & F:CAACATCCTTTACCCATTGACAGA & \multirow{3}{*}{76} & \multirow{3}{*}{1.94} & \multirow{3}{*}{60} & \multirow{3}{*}{78.6} \\
\hline & & & & & \\
\hline XM_002285134.3 & R:GCATTTGATCCACTTGCAGATAAG & & & & \\
\hline \multicolumn{6}{|l|}{ Target gene } \\
\hline VviSBT4.19 X1 & F:AATCCTGGTGTTCTTGTGG & \multirow{2}{*}{73} & \multirow{2}{*}{2.04} & \multirow{2}{*}{58} & \multirow{2}{*}{72.3} \\
\hline XM_010660203.2 & R:ATTAGGTAAAATGTTGTGCTTG & & & & \\
\hline
\end{tabular}

Thermal cycling for all genes started with a denaturation step at $95^{\circ} \mathrm{C}$ for $10 \mathrm{~min}$, followed by 40 cycles of denaturation at $95{ }^{\circ} \mathrm{C}$ for $15 \mathrm{~s}$ and annealing (Table 1) for $30 \mathrm{~s}$. For each set of reactions, a negative control without cDNA template was included. Three biological and two technical replicates were analysed for each treatment. Dissociation curves were used to analyse non-specific PCR products (data not shown). Gene expression (fold change) was calculated using Hellemans method (Hellemans et al., 2007). The reference genes used for the normalization were Elongation factor 1-alpha (EF1a) (Pessina, 2016) and Glyceraldehyde-3phosphate dehydrogenase (GADPH) (Welter et al., 2017 ) for the $V$. vinifera-E. necator interaction and EF $1 \alpha$ (Gruau et al., 2015) and SAND family protein (SAND) (Nanni et al., 2014) for the V. vinifera-B. cinerea interaction. Statistical significance $(\mathrm{p}<0.05)$ 
of gene expression was determined by the MannWhitney U test using IBM ${ }^{\circledR}$ SPSS $^{\circledR}$ Statistics version 23.0 software (SPSS Inc., USA).

\section{RESULTS AND DISCUSSION}

In Vitis vinifera cv 'Regent' plants inoculated with Plasmopara viticola, a subtilase, VviSBT4.19 X1, potentially involved in the establishment of an effective defence response against pathogens, was identified (Figueiredo et al., 2016). In the present work, the gene expression of VviSBT4.19X1 subtilase in 'Regent' after inoculation with the biotrophic pathogen Erysiphe necator and with the necrotrophic fungus Botrytis cinerea was accessed. The aim is to understand if VviSBT4.19 Xlis associated to hostpathogen specificity or if it is part of a broader defence mechanism against pathogens with different infection strategies.

$V$. vinifera $\mathrm{cv}$ 'Regent' leaves were inoculated either with E. necator or B. cinerea and harvested at 6 and 24 hpi. In 'Regent' inoculated with E. necator, no significant difference in gene expression between inoculated and non-inoculated leaves after 6 hpi (1.86 \pm 0.91 fold) was observed, while a slight downregulation at $24 \mathrm{hpi}(0.55 \pm 0.06$ fold $)$ was detected (Figure 1). After inoculation of 'Regent' leaves with $B$. cinerea, no significant differences in VviSBT4.19 $X 1$ gene expression were also observed, in both analysed time-points ( 6 hpi: $0.84 \pm 0.12$ fold; 12 hpi: $1.09 \pm 0.09$ fold $)-$ Figure 1 . These results show that the infection of 'Regent' by these two pathogens does not appear to induce a significant variation in the level of expression of the VviSBT4.19X1 gene. As such, it seems that this particular subtilase did not have a relevant role in the defence response of 'Regent' to E. necator and B. cinerea, at least in the first hours after inoculation. However, when compared to our previous results on 'Regent' inoculated with $P$. viticola, in which $V$ viSBT4.19 X1 presented a significant expression increase at both 6 and $24 \mathrm{hpi}$, our combined results may suggest some specificity of this subtilase towards $P$. viticola.

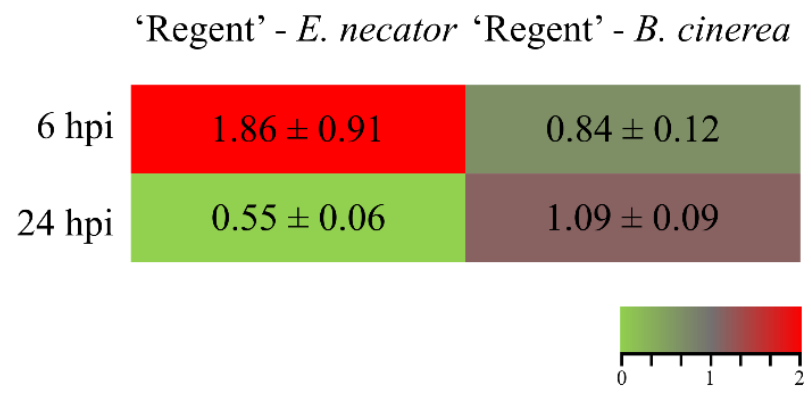

Figure 1. Gene expression profile of VviSBT4.19X1 in Vitis vinifera cv. 'Regent' leaves at 6 and 24 hours after inoculation (hpi) with Erysiphe necator and Botrytis cinerea.

Perfil de expressão genética de VviSBT4.19X1 em folhas de Vitis vinifera cv. 'Regent' às 6 e 24 horas após a inoculação (hpi) com Erysiphe necator e Botrytis cinerea.

Specificity of host-pathogen associations can be explained to a large extent by major genes of hosts and pathogens, as in the gene-for-gene model of plant-pathogen compatibility (Jones and Dangl, 2006). In fact, several studies have pointed out that some subtilases, particularly the tomato P69, are induced by a specific pathogen (Vera and Conejero, 1988; Vera et al., 1989; Tornero et al., 1996a). P69 is responsible for the cleavage of a leucine-rich repeat protein (LRP) associated with the extracellular matrix, contributing for the plant immunity establishment (Tornero et al., 1996b).

Few studies have been conducted in serine proteases role in grapevine-pathogen interaction. Transcriptome characterization studies have shown that several serine proteases are modulated in response to $P$. viticola (Figueiredo et al., 2012), E. necator (Weng et al., 2014) and B. cinerea (Dadakova et al., 2015). However, their role still remains uncovered. In grapevine- $P$. viticola interaction, studies have highlighted a specificity between $P$. viticola secretome and plant serine proteases. Gindro et al. (2012) have hypothesized that $P$. viticola inhibits the endogenous subtilases of susceptible varieties, thereby inhibiting the plant's normal defence reaction, whereas resistant or immune varieties may possess endogenous subtilases that are not recognized because of slight structural modifications of the 
protein patterns of these cultivars (Gindro et al., 2012).

A full understanding of serine proteases role in grapevine-pathogen interactions is crucial. These results provide the first clues suggesting that hostpathogen specificity may occur in the case of VviSBT4.19X1.

\section{CONCLUSIONS}

In the present work, the gene expression of VviSBT4.19X1 in 'Regent'-E. necator and 'Regent'$B$. cinerea interactions was analysed and no significant up-regulation of gene expression was observed in both pathosystems. These results lead us to hypothesize a host-pathogen specificity for VviSBT4.19 X1. However, until now, it has not been proved that, within a plant genotype, a subtilase participates in the defence response exclusively against a specific pathogen. Genes like VviSBT4.19 $X 1$, which are only activated in response to a specific pathogen, are strong resistance biomarkers that can be used in the screening of new grapevine crossing lines in breeding programs. Further work is being developed to gain more information into VviSBT4.19 $X 1$ specificity, namely full time-course assays with the three pathogens.

\section{ACKNOWLEDGEMENTS}

This work was supported by the Portuguese Foundation for Science and Technology (FCT, Portugal) funded fellowships and contracts to Andreia Figueiredo, Marta Sousa Silva, and Joana Figueiredo: IF/00819/2015, CEECIND/02246/2017, SFRH/BD/137066/2018. FCT funded the Research Units and project: BioISI (UID/MULTI/04046/2019), and the project PTDC/BIA-BQM/28539/2017. We would like to thank Dr. Filomena Duarte (INIAV Estação Vitivinícola Nacional, Dois Portos, Portugal) for the Botrytis cinerea pre-inocula used in the inoculation experiments.

\section{REFERENCES}

Armijo G., Schlechter R., Agurto M., Muñoz D., Nuñez C., ArceJohnson P., 2016. Grapevine pathogenic microorganisms: understanding infection strategies and host response scenarios. Front. Plant Sci., 7, 382.

Dadakova K., Havelkova M., Kurkova B., Tlolkova I., Kasparovsky T., Zdrahal Z., Lochman J., 2015. Proteome and transcript analysis of Vitis vinifera cell cultures subjected to Botrytis cinerea infection. J. Proteomics, 119, 143-153.
Dean R., Van Kan J.A.L., Pretorius Z.A., Hammond-Kosack K.E., Di Pietro A., Spanu P.D., Rudd J.J., Dickman M., Kahmann R., Ellis J., Foster G.D., 2012. The Top 10 fungal pathogens in molecular plant pathology. Mol. Plant Pathol., 13, 414-430.

Duan X., Zhang Z., Wang J., Zuo K., 2016. Characterization of a novel cotton subtilase gene GbSBT1 in response to extracellular stimulations and its role in Verticillium resistance. PLOS ONE, 11, e0153988

Figueiredo A., Monteiro F., Fortes A.M., Bonow-Rex M., Zyprian E., Sousa L., Pais M.S., 2012. Cultivar-specific kinetics of gene induction during downy mildew early infection in grapevine. Funct. Integr. Genomics, 12, 379-386.

Figueiredo J., Costa G.J., Maia M., Paulo O.S., Malhó R., Sousa Silva M., Figueiredo A., 2016. Revisiting Vitis vinifera subtilase gene family: a possible role in grapevine resistance against Plasmopara viticola. Front. Plant Sci., 7, 1783.

Figueiredo J., Sousa Silva M., Figueiredo A., 2018. Subtilisin-like proteases in plant defence: the past, the present and beyond. Mol. Plant Pathol., 19, 1017-1028.

Gadoury D.M., Cadle-Davidson L., Wilcox W.F., Dry I.B., Seem R.C., Milgroom M.G., 2012. Grapevine powdery mildew (Erysiphe necator): a fascinating system for the study of the biology, ecology and epidemiology of an obligate biotroph. Mol. Plant Pathol., 13, $1-16$.

Gessler C., Pertot I., Perazzolli M., 2011. Plasmopara viticola: a review of knowledge on downy mildew of grapevine and effective disease management. Phytopathol. Mediterr., 50, 3-44.

Gindro K., Berger V., Godard S., Voinesco F., Schnee S., Viret O., Alonso-Villaverde V., 2012. Protease inhibitors decrease the resistance of Vitaceae to Plasmopara viticola. Plant Physiol. Biochem., 60, 74-80.

Gruau C., Trotel-Aziz P., Villaume S., Rabenoelina F., Clément C., Baillieul F., Aziz A., 2015. Pseudomonas fluorescens PTA-CT2 triggers local and systemic immune response against Botrytis cinerea in grapevine. Mol. Plant. Microbe Interact., 28, 11171129.

Hellemans J., Mortier G., De Paepe A., Speleman F., Vandesompele J., 2007. qBase relative quantification framework and software for management and automated analysis of real-time quantitative PCR data. Genome Biol., 8, R19.

OIV, 2019. World vitiviniculture situation: OIV statistical report on world vitiviniculture. Available at: http://oiv.int/public/medias/6782/oiv-2019-statistical-report-onworld-vitiviniculture.pdf (assessed on 18.04.2020).

Jarvis W.R., 1962. The dispersal of spores of Botrytis cinereafr. in a raspberry plantation. Trans. Br. Mycol. Soc., 45, 549-559.

Jones J.D.G., Dangl J.L., 2006. The plant immune system. Nature, 444, 323-329.

Martins I., 2018. Património único que se distingue e valoriza pela diversidade de castas. Portugal global, 109, 7-11.

Maul E., Töpfer R., 2015. Vitis International Variety Catalogue (VIVC): A cultivar database referenced by genetic profiles and morphology. BIO Web Conf., 5, 01009.

Nanni V., Schumacher J., Giacomelli L., Brazzale D., Sbolci L., Moser C., Tudzynski P., Baraldi E., 2014. VvAMP2, a grapevine flower-specific defensin capable of inhibiting Botrytis cinerea 
growth: insights into its mode of action. Plant Pathol., 63, 899910.

Norero N.S., Castellote M.A., de la Canal L., Feingold S.E., 2016. Genome-wide analyses of subtilisin-like serine proteases on Solanum tuberosum. Am. J. Potato Res., 93, 485-496.

Pessina S., 2016. Role of MLO genes in susceptibility to powdery mildew in apple and grapevine. $222 \mathrm{p}$. PhD Thesis, Wageningen University.

This P., Lacombe T., Thomas M.R., 2006. Historical origins and genetic diversity of wine grapes. Trends Genet., 22, 511-519.

Tian M., 2005. A second Kazal-like protease inhibitor from Phytophthora infestans inhibits and interacts with the apoplastic pathogenesis-related protease P69B of tomato. Plant Physiol., 138, 1785-1793.

Tian M., Huitema E., Cunha L. da, Torto-Alalibo T., Kamoun S., 2004. A Kazal-like extracellular serine protease inhibitor from Phytophthora infestans targets the tomato pathogenesis-related protease P69B. J. Biol. Chem., 279, 26370-26377.

Tornero P., Conejero V., Vera P., 1996a. Primary structure and expression of a pathogen-induced protease (PR-P69) in tomato plants: similarity of functional domains to subtilisin-like endoproteases. Proc. Natl. Acad. Sci., 93, 6332-6337.

Tornero P., Mayda E., Gómez M.D., Cañas L., Conejero V., Vera P., 1996b. Characterization of LRP, a leucine-rich repeat (LRR) protein from tomato plants that is processed during pathogenesis. Plant J., 10, 315-330.
Vandesompele J., De Preter K., Pattyn F., Poppe B., Van Roy N., De Paepe A., Speleman F., 2002. Accurate normalization of realtime quantitative RT-PCR data by geometric averaging of multiple internal control genes. Genome Biol., 3, research0034.

Veloso M.M., Almandanim M.C., Baleiras-Couto M., Pereira H.S., Carneiro L.C., Fevereiro P., Eiras-Dias J., 2010. Microsatellite database of grapevine (Vitis vinifera L.) cultivars used for wine production in Portugal. Ciência Téc. Vitiv., 25, 53-61.

Vera P., Conejero V., 1988. Pathogenesis-related proteins of tomato P-69 as an alkaline endoproteinase. Plant Physiol., 87, 5863.

Vera P., Yago J.H., Conejero V., 1989. Immunogold localization of the citrus exocortis viroid-induced pathogenesis-related proteinase P69 in tomato leaves. Plant Physiol., 91, 119-123.

Welter L.J., Tisch C., Kortekamp A., Töpfer R., Zyprian E., 2017. Powdery mildew responsive genes of resistant grapevine cultivar "Regent.” VITIS - J. Grapevine Res., 56, 181-188.

Weng K., Li Z.-Q., Liu R.-Q., Wang L., Wang Y.-J., Xu Y., 2014. Transcriptome of Erysiphe necator-infected Vitis pseudoreticulata leaves provides insight into grapevine resistance to powdery mildew. Hortic. Res., 1, 1-12.

Zhao Y., Thilmony R., Bender C.L., Schaller A., He S.Y., Howe G.A., 2003. Virulence systems of Pseudomonas syringae pv. tomato promote bacterial speck disease in tomato by targeting the jasmonate signaling pathway. Plant J., 36, 485-499. 